\title{
California court forces closure of biology laboratory
}

\section{San Francisco}

LEGAL precedent was set earlier this month when the state Court of Appeal ordered research to be halted at the pharmacology school of the University of California at San Francisco. It is believed to be the first time that a court has shut down a major university facility to allay public fears over the dangers of research in molecular biology.

The action is the second of two unexpected defeats for the university in a longrunning battle with a neighbourhood association opposing the opening of a laboratory at Laurel Heights in San Francisco. In July the Court of Appeal ruled that the university's environmental impact report was inadequate. In August this was followed by an injunction to close the laboratory for 90 days. Only rapid action by the state Supreme Court saved the research programme from destruction.
Two days into the shutdown the court granted the university temporary emergency relief from the injunction but followed this with a decision barring the laboratory from using radioisotopes.

The Court of Appeal's decision stunned university researchers. The environmental impact report prepared for public scrutiny had cited detailed evidence that the research was no different from that carried out at molecular biology laboratories elsewhere and was not dangerous to the public. Among that evidence was data collected at the university's main campus showing that there was no increase in levels of toxic or radioactive chemicals in areas near similar laboratories. That has since been backed up with a study commissioned from the Radian Corporation showing that, in the worst case, exposure of the local community to Laurel Heights laboratory emissions

\section{A new future for Israeli defence research in the balance?}

\section{Rehovot}

THE fate of the new Lavi fighter remains in the balance after a vote to decide the controversial fighter's future at this week's Israeli cabinet meeting was postponed. Lavi, a project that would propel Israel into the big leagues of military hardware production, has been sharply criticized both within the country and by the United States as project costs rose a long way above expected levels. But the debate over Lavi points up the need seen by many to bring about drastic changes in Israeli defense research, given the country's current economic situation.

Dr Zeev Bonen, outgoing director general of RAFAEL, the Israel weapons development authority, says projects such as Lavi, the Merhava tank and the Saar missile boat are simply too costly for a country the size of Israel to undertake on its own. Bonen favours multinational development cheaper weapons systems.

As director of RAFAEL from 1970 to 1978 and again from 1982 until last month, Bonen was at the centre of the accelerated defence research and development effort that began after French President Charles de Gaulle embargoed all arms shipments to Israel following the Six Day War in 1967. But the push for independence in arms "had a major weakness", says Bonen.

It was carried out with "a complete disregard of the economic imperative". Demand in Israel for weapons produced domestically "has almost always been far below the break-even point in economic terms", says Bonen. Exporting weapons has been difficult, because many countries have political objections to buying Israeli arms, and competition in arms sales is fierce.

But multinational collaboration has its own difficulties. Because Israel will almost always be a junior partner in joint projects, there is a legitimate fear that Israeli science-based industry would be denied a significant role in the research, development and production process.

Maintaining adequate levels of security is also a problem in cooperative ventures.

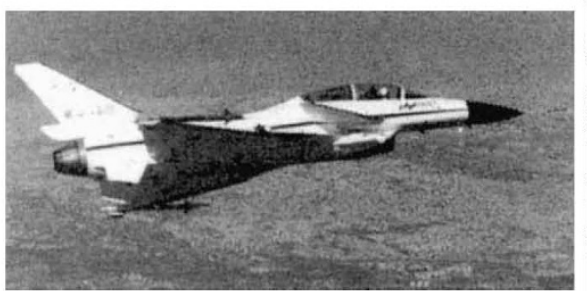

Lavi - too costly for Israel alone?

"Secrecy norms in the West are completely different from ours", says Bonen.

Many in Israel - including those in the armed forces - agree that projects such as Lavi are too ambitious for a small country to undertake. For two decades, the push for total self-sufficiency in arms has guided Israeli military research, development and production, says Bonen. Despite the difficulties, he believes economic and political reality dictates that this policy must change. "would be from 600 times to 500 million times less than levels known to be safe." The studies have not persuaded local residents. Accusations have been made that one of the researchers, Dr Nina Agabian, is involved in "biological warfare research". Dr Agabian is in fact a molecular parasitologist studying vaccines that may be of value in the third world. The university has repeatedly stressed that it does not do classified research.

The university's attorney, Etan Schulman, believes that local residents' response "may reflect a fear of technology and the unknown that is perhaps understandable in the light of the Chernobyl accident". Others are less charitable and perceive a deliberate campaign of misinformation by those who oppose any university expansion in residential areas. Either way, $\mathrm{Mr}$ Schulman is concerned that the courts may now be putting an unrealistic burden of proof on the university. In ruling the environmental impact report inadequate the court seemed to suggest that the rule of "substantial evidence" should be replaced by an impossible demand that the university must prove that their activities could never produce any harmful effect.

To restart its plans, the university must now win state Supreme Court appeals on both the injunction and the adequacy of the environmental impact report. The court has 60 days to decide whether to hear the appeals or simply to let the lower court decision stand

The dispute already appears to have damaged the university. Several cell biologists have sought work elsewhere rather than risk delay. But the university is not necessarily blameless. In acquiring the Laurel Heights site it said that the research to be conducted there would be "academic" - a term more redolent of the library than the laboratory. Only much later did it start to speak of "academic and scientific research". With many universities anxious to expand urban campuses the need for skilled public relations is sure to grow.

Alun Anderson

East German base now independent?

\section{London}

EAST Germany is to have its own research station in the Antarctic. For some years, the East German Academy of Sciences has maintained an Antarctic research programme at the Soviet Novalazarevskaya station. On 1 July, however, the East German "Georg Foster" base became fully independent, and the first solely East German expedition will set out in October with a research programme including meteorology, geophysics, geology, atmospheric physics, isotope research, environmental studies and biology. Vera Rich 